\title{
Por amor à arte
}

\author{
LEYLA PERRONE-MOISÉS*
}

Q

UERO PRIMEIRAMENTE agradecer o convite tão honroso de vir aqui falar sobre um tema que para mim é novo. Nunca fiz conferência sobre mim mesma, e isso me embaraça um pouco porque, como crítica, gosto muito de falar dos outros, dos escritores. De mim mesma, não gosto muito de falar. Outra coisa que não é muito do meu agrado é fazer revisões, voltar ao passado. Quando alguém diz "vamos ouvir essa música, que é do nosso tempo", não gosto. Meu tempo é hoje. Portanto, é assim com um movimento duplo, de vago embaraço e de satisfação real, que me vejo acolhida aqui na Academia, uma honra muito grande. Agradeço muito aos acadêmicos, em especial a Antonio Carlos Secchin, organizador deste ciclo. Por outro lado, espero não aborrecê-los com o tema desta conferência. Não será propriamente uma conferência. Vou falar de modo informal, seguindo algumas anotações, e de vez em quando vou ler um trecho escrito, porque em algumas ocasiões já tive de escrever sobre alguns aspectos da minha carreira intelectual.

Todo autor de biografia tende a começar pela infância. Na autobiografia intelectual, necessariamente, são os primeiros livros, as primeiras leituras. O primeiro livro que li na minha vida, aos cinco anos, se chamava Rosa Maria no Reino Encantado, de Érico Veríssimo. Portanto, comecei bastante bem. Tenho ainda esse livro, em que inscrevi meu nome com umas letrinhas tortas. Logo em seguida, passei para Monteiro Lobato. Sobre isso, vou dizer algumas coisas porque, se não são importantes, pelo menos formam uma figura.

Passei a minha infância numa cidadezinha de Minas Gerais, Passa-Quatro, num vale da serra da Mantiqueira, perto de São Lourenço, no circuito das águas. A família italiana do meu pai, Perrone, tinha imigrado para lá no fim do século XIX. Nasci em São Paulo, porque minha mãe era paulista, mas passei onze anos da minha vida naquela cidadezinha. Em casa, tínhamos um quintal muito grande, com muitas árvores frutíferas, e levávamos uma vida quase que de sítio. Então li Monteiro Lobato num contexto de Sítio do Pica-Pau Amarelo, porque lia seus livros em cima de uma árvore, uma amoreira que eu considerava minha. Subia, sentava-me num galho lá em cima, e assim li todo o Monteiro Lobato. Não havia o Rabicó, mas havia as galinhas etc. E eu tinha uma tia Anastácia, porque a cozinheira era uma negra muito escura que, de um modo politicamente incorreto, tinha o apelido de Vavão. Era como nós, crianças, pronunciávamos "carvão". Mas acho que foi ela mesma que se auto-apelidou Vavão.

* Depoimento dado durante o III Ciclo de Conferências "Caminhos do Crítico", na Academia Brasileira de Letras, em 24 de maio de 2005. 
Minha mãe, como todas as mulheres de sua geração, admirava muito a França, embora não falasse francês, e achava que o ideal era que uma futura moça falasse francês e tocasse piano. Então, tive aulas de francês desde os sete anos de idade, e de piano também. $O$ piano não deu em nada. $O$ francês continuou. $O$ interessante, agora que vejo retrospectivamente, é que, além dessa cozinheira, eu e meu irmão tínhamos uma babá, que era filha da cozinheira e do meu professor de francês. Ele se chamava Ulysse Courbassier. Era um Ulisses que não tinha voltado da viagem. Tinha ido parar, não sei como, lá na serra da Mantiqueira, e tinha tido uma filha com aquela Vavão. Portanto, parece que o meu destino França-Brasil já estava ali, porque a minha babá era franco-brasileira. Era só isso que eu queria dizer da minha infância.

Continuando esta "terapia de vidas passadas", vou falar agora de minha adolescência. Meu projeto de vida não era escrever, era pintar. Eu queria ser pintora. E até fui, pelo seguinte: freqüentei vários cursos livres de belas-artes, desde os catorze anos. Naquela década de 1950, começaram as bienais de São Paulo. Para mim, como para toda a gente, foi uma revelação da arte do mundo, da arte moderna. Eu ia ver as bienais, e escrevia minhas impressões num caderninho. Anotei o nome de um pintor de que eu tinha gostado muito: Samson Flexor. Pouco depois, fiquei excitadíssima quando soube que ele morava em São Paulo e dava aulas de pintura.

Meus pais, felizmente, sempre encorajaram tudo que fosse cultura, arte. Eu lhes pedi para ter aulas com o Flexor. Assim, aos dezesseis anos, eu já fazia parte de algo que agora é um capítulo da história da pintura moderna brasileira: o Ateliê Abstração de Samson Flexor. Eu era a mais jovem do grupo. Como participante do Ateliê, expus em duas bienais de São Paulo, na quarta e na quinta, quando havia júris, junto com os maiores nomes de artistas plásticos do país. Tudo isso hoje me parece quase impossível - por isso disse que este depoimento se parece com uma terapia de vidas passadas. Mas os catálogos das bienais estão lá, para quem os quiser ver. Participei de várias exposições coletivas do Ateliê Abstração, uma delas em Nova York, e fiz uma exposição individual na Galeria da Folha.

Depois de alguns anos, de repente, a pintura acabou. Ao mesmo tempo, a paixão pela literatura nasceu e cresceu. Quando a pintura acabou, eu já estava no fim do curso de Letras. Eu teria preferido ir para a Escola de Belas-Artes, mas meus pais me disseram: "Pintora não é profissão!" Eles se enganavam muito porque, se eu fizesse sucesso, ganharia muito mais do que como professora de Letras. Então disseram: "Pagamos o curso de pintura, mas faça um curso que dê uma profissão, você gosta de literatura, então faça Letras".

Em dezembro de 1958, mandei uma resenha de um livro francês para o Suplemento Literário de O Estado de S. Paulo, e foi aceita. Era sobre La modification, de Michel Butor. Continuei fazendo resenhas de livros franceses no Suplemento Literário. Era uma etapa que começava e foi importantíssima para a 


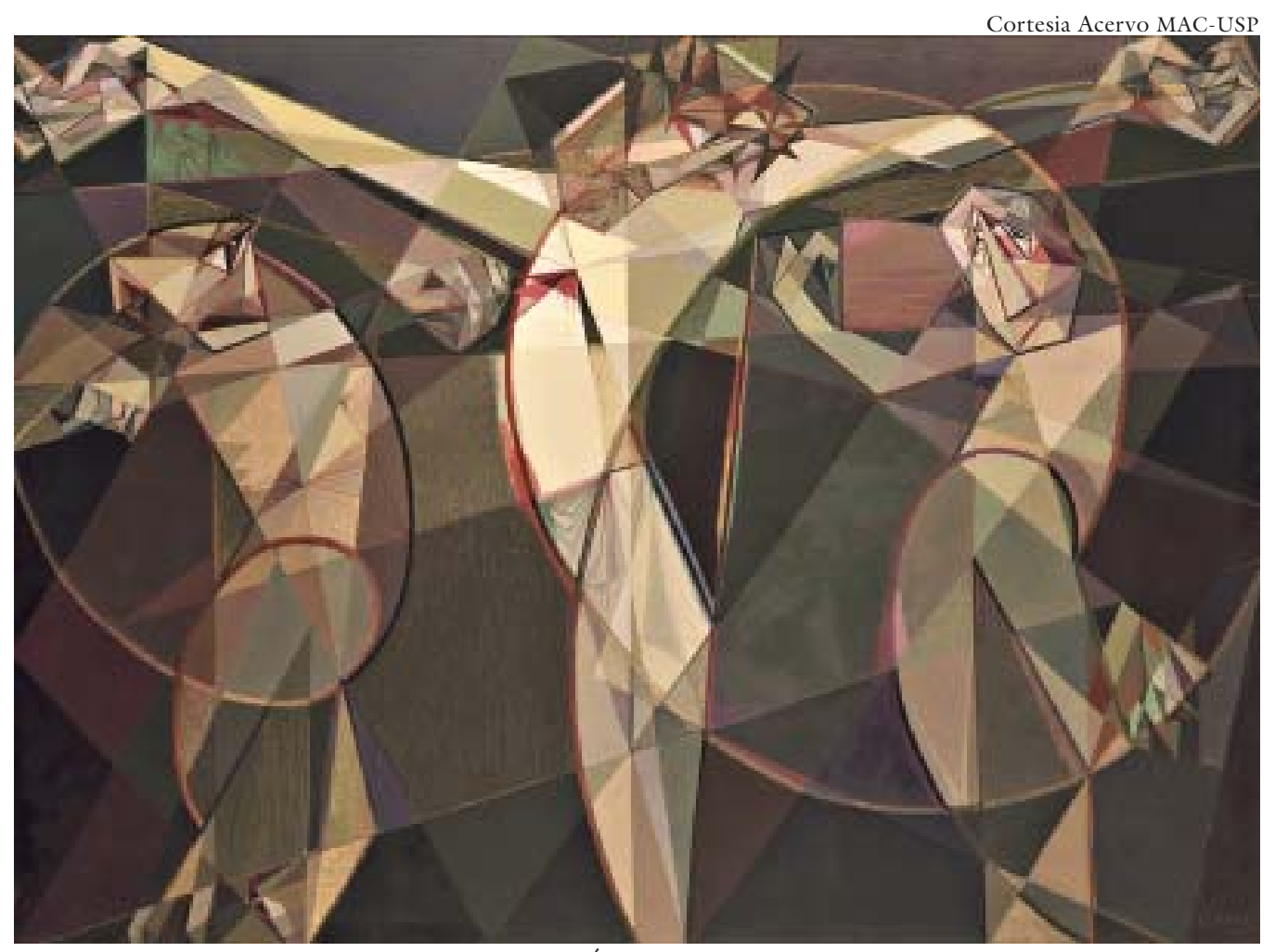

Samson Flexor, Cristo na cruz, 1949. Óleo s/tela, 145.0 x 193.3.

minha carreira intelectual. Eu tinha sido uma boa aluna de francês, no colégio. Aos dezoito anos, já tinha o diploma de curso superior da Aliança Francesa, e tinha até ganho uma bolsa para a França. Mas, evidentemente, a viagem não foi autorizada por meus pais. Imaginem, Paris, aquela cidade de perdição... Então, como é que eu, aos dezoito anos, nos anos de 1950, iria sozinha para Paris? Não fui, teria de esperar um pouco mais.

Continuei a escrever no Suplemento de O Estado de S. Paulo, que agora é um suplemento mítico, porque muitos o consideram o melhor suplemento literário e cultural que houve no Brasil. De fato, era um suplemento que tinha os maiores nomes da literatura, da poesia e das artes plásticas, porque nele havia também notáveis ilustrações. O diretor do Suplemento era o Décio de Almeida Prado, a inspiração era do Antonio Candido. Portanto, o Suplemento Literário foi uma descendência do grupo da revista Clima.

Todas essas coisas parecem, agora, mais antigas do que são. Naquele tempo, eu falava dos livros que tinham acabado de sair na França, e as citações que eu colocava no Suplemento Literário eram em francês. Era o momento do nouveauroman. As pessoas iam à livraria francesa e compravam aqueles livros. A cultura francesa hoje não tem nem um décimo da importância que tinha para a intelectualidade brasileira naquele momento, embora já estivesse declinando. Afinal, sou uma afrancesada um pouco atrasada, porque o grande momento do afrancesamento foi anterior a mim. 


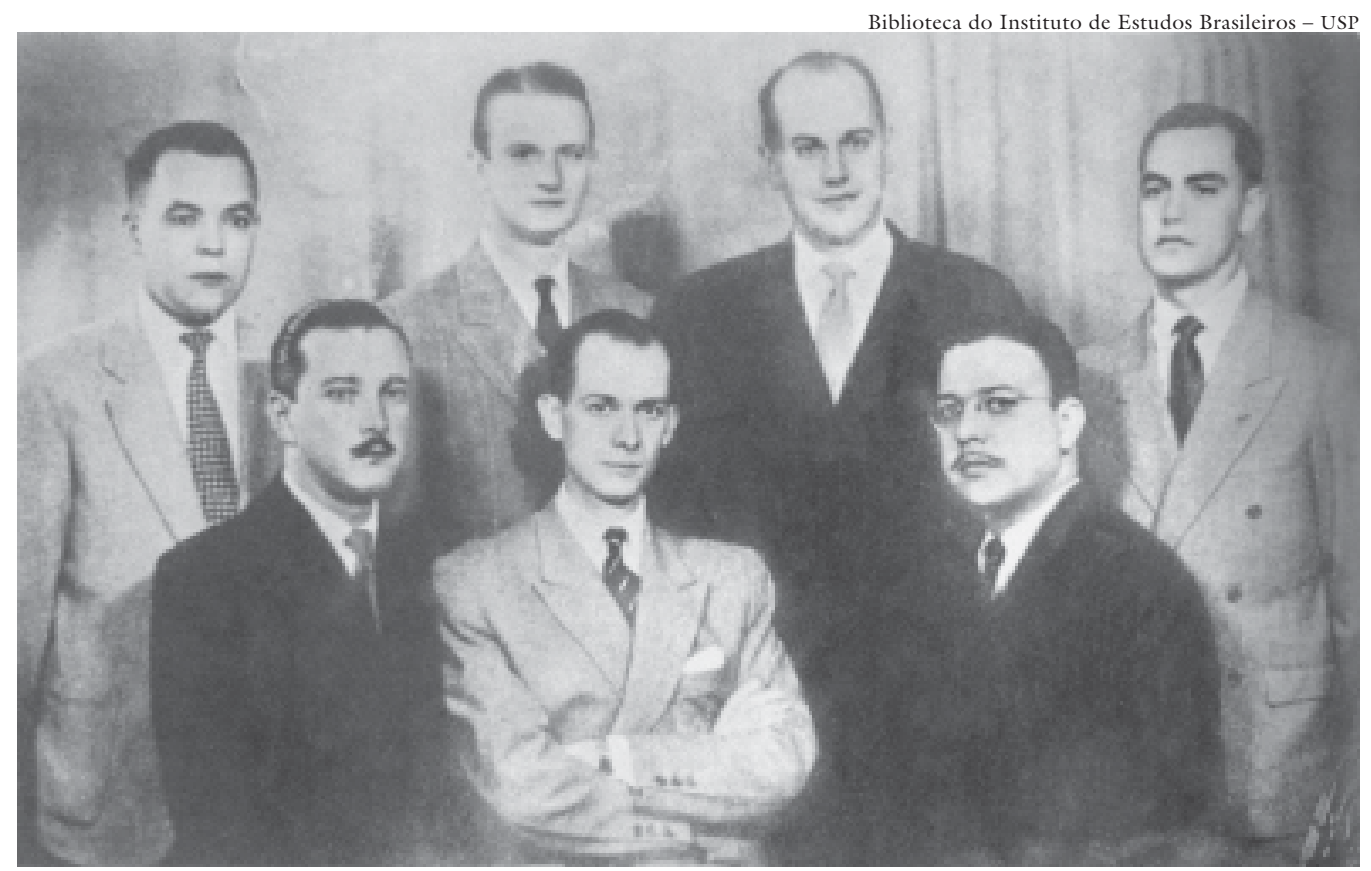

Grupo da revista Clima, c. 1941. Da esquerda para a direita, em pé: Antonio Branco Lefèvre, Décio de Almeida Prado, Paulo Emilio Salles Gomes e Roberto Pinto Souza. Sentados: Alfredo Mesquita, Antonio Candido e Lorival Gomes Machado.

O Suplemento Literário tinha colunas fixas: "Letras inglesas", "Letras alemãs", "Letras italianas", "Letras francesas". Quem fazia as letras francesas era o Brito Broca, magnificamente, com toda a erudição dele. Aí, faleceu o Brito Broca. Décio de Almeida Prado teve uma grande coragem, porque me telefonou e me perguntou se eu queria assumir aquela coluna. Fiquei absolutamente apavorada. Como poderia substituir o Brito Broca? Aí foi uma mudança total, inclusive da coluna "Letras francesas". Brito Broca era um erudito, um profundo conhecedor da história da literatura brasileira e da literatura francesa. Eu comecei a falar das coisas da atualidade da França, principalmente do nouveau roman. Logo em seguida, isso se ligou ao desenvolvimento da teoria literária na França, nos anos de 1960. E essas coisas interessavam aos intelectuais e escritores brasileiros.

Tive a satisfação de ouvir, de alguns grandes escritores, que eles liam meus artigos sobre o novo romance, e que isso foi importante para eles. Por exemplo, o Osman Lins me lia, e o Raduan Nassar, mesmo que fosse para rejeitar os princípios do novo romance. Raduan Nassar me disse: "Eu comprava e lia todos os livros que você recomendava. Depois cheguei à conclusão de que aquilo não era para mim". Então, esses artigos tinham uma função de alimentar as letras brasileiras, mesmo que indiretamente. De minha experiência do Suplemento, resultou meu primeiro livro, O novo romance francês, que foi uma recolha dos artigos publicados sobre o tema no jornal.

Antes de passar a outra etapa, eu gostaria de ler um fragmento do que escrevi sobre Décio de Almeida Prado e o Suplemento Literário:

O Suplemento Literário, graças à direção de Décio de Almeida Prado, que era 

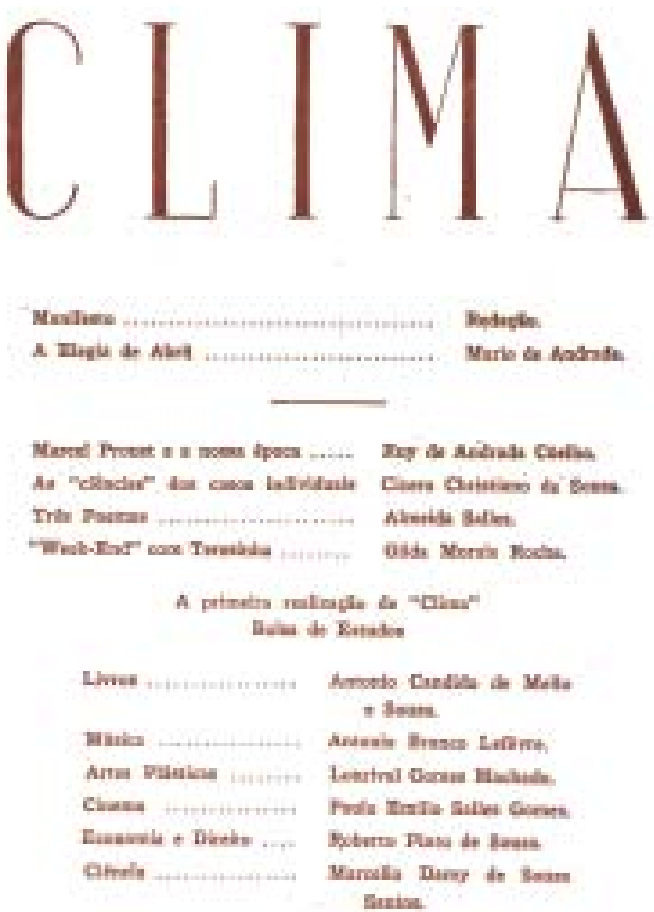

Capa da $1^{\underline{a}}$ edição

São Paulo - Maio de 1941 - N, 1 da revista Clima.

firme na manutenção da qualidade mas deixava grande liberdade aos colaboradores, mesmo aos jovens principiantes como eu, foi uma obra excepcional, tanto em termos de Brasil como em termos internacionais. Entre nós, nunca mais a imprensa cultural atingiu aquele nível. Com Décio, escritor e diretor, aprendi um estilo de jornalismo cultural. Habituei-me a escrever para um público amplo, que busca uma informação de qualidade e não uma especulação intelectual autotélica. Aprendi que ser claro e sintético não é necessariamente ser superficial. Que escrever para jornal deve implicar uma atitude democrática e sedutora.

Quando comecei a escrever e a publicar, não tinha nenhuma teoria a respeito da literatura e da crítica literária (nos cursos de letras não havia disciplina alguma que o ensinasse); mas tinha modelos, os grandes intelectuais que escreviam no Suplemento. E Décio me ensinava, sem nenhuma lição explícita, uma postura que era a de sua geração: uma certa elegância discreta, uma seriedade não desprovida de humor. Bem ou malsucedida nessa aprendizagem, sou, quanto ao estilo, cria do Suplemento Literário. Por ter escrito mais de uma centena de artigos no Suplemento, antes de escrever uma tese universitária, talvez minhas teses e livros tenham conservado algumas características daquele jornalismo cultural. 
Vou falar, agora, daquilo que passou da experiência de pintura para a experiência de crítica. Meu abandono da pintura não foi uma ruptura total. $\mathrm{O}$ ensinamento de Flexor permaneceu ativo em minha apreciação das obras literárias. Um romance ou um poema, como um quadro ou uma composição musical, são feitos de um arcabouço invisível de linhas de força, um jogo de valores, contrastes cromáticos, retomadas sutis de temas antes anunciados. Portanto, como crítica, vi muita similitude entre a composição de um livro e a de um quadro.

É bom que um crítico tenha uma experiência, mesmo que pequena, dos processos internos da criação. Depois de minha experiência com a pintura abstrato-geométrica, minhas preferências literárias orientaram-se naturalmente para as obras em que a expressão é controlada por uma tendência construtiva: o novo romance, o estruturalismo, a poesia de linhagem mallarmeana. Ficaram-me, do ensino de Flexor, algumas disposições definitivas: a desconfiança da representação artística da realidade como "realismo" e como expressão do "ego"; o gosto pelo experimentalismo; o respeito pelo trabalho do artista que conhece seu ofício; e uma grande paixão pela arte como algo maior do que o indivíduo artista. Toda uma concepção moderna da arte, que era do meu mestre Flexor, e que atualmente é vista por muitos como ultrapassada.

Agora vou dizer alguma coisa sobre minha carreira universitária. Eu me licenciei em Letras Neolatinas - naquele tempo o curso de Letras Modernas dividia-se em Letras Neolatinas e Letras Anglo-germânicas - na Faculdade de Filosofia da Universidade de São Paulo. Fiz o meu doutorado em 1971, com uma tese sobre Lautréamont, que resultou no livro Falência da crítica. Um caso limite: Lautréamont. Fazendo agora este retrospecto, vejo que todos os meus livros tratam da crítica literária. Ao escolher o tema de minha tese, eu pretendia trabalhar sobre Isidore Ducasse, o Conde de Lautréamont. Mas ao ler o que se havia escrito sobre ele, comecei a refletir sobre os métodos críticos, seu alcance e seus limites, principalmente diante de um objeto não-identificado como era Lautréamont. Não se sabia quase nada de sua biografia, portanto não podia haver uma crítica baseada no homem que ele foi. Sabia-se que era franco-uruguaio, portanto não pertencia a nenhuma sociedade precisa. Sua obra desobedecia a todas as regras de escola ou de gênero. Esse meu primeiro livro acabou sendo menos um livro sobre Lautréamont do que uma reflexão teórica sobre a crítica literária moderna.

Em 1975, defendi minha tese de livre-docência, sobre a "crítica-escritura", que resultou no livro Texto, crítica, escritura, publicado em 1978. Esse livro está sendo reeditado agora pela Editora Martins Fontes, com a argüição de Antonio Candido, que continua muito interessante tantos anos depois. Eu tratava aí de um tipo de crítica que misturava crítica e criação e, como exemplos, sempre na área de escritores da literatura francesa, estudei Maurice Blanchot, Michel Butor e Roland Barthes.

Depois, passando muito rapidamente pelo meu currículo - professora adjunta, titular em 1986 - me aposentei em 1988. Em 1999 recebi o título de 
Professora Emérita. Enquanto isso, e desde recém-formada, fui professora em vários lugares, porque até os anos de 1970 era muito difícil ter tempo integral na Universidade de São Paulo. Não havia muita verba para isso. Então, tive de dar aulas em outros lugares. Dei aulas no curso secundário, no Colégio Sion, fui professora da PUC de São Paulo na década de 1960, co-fundadora da área de pós-graduação em Teoria Literária daquela Universidade, até 1975, quando obtive tempo integral na Universidade de São Paulo.

As minhas principais temporadas no exterior, como todos devem desconfiar, foram principalmente na França. Ia sempre durante as férias, passava as férias de verão daqui no inverno lá, em 1968, 1969, 1970, isto é, em plena época de efervescência teórica na França. Cheguei a Paris não só para aprender, mas com coisas para mostrar. Tudo isso, quando a gente vive, não percebe. Por exemplo, o meu encontro com Roland Barthes. Eu já tinha publicado no Suplemento Literário dois artigos longos sobre ele, e ele ainda não era tão famoso como se tornou depois. Conheci uma secretária que trabalhava para ele e ela me disse: "Vou apresentá-la a Roland Barthes". Levei comigo os artigos e dei-os a ele. Ele, muito gentilmente, pediu o meu endereço e, dois dias depois, recebi uma cartinha dele dizendo que queria me ver, porque tinha percorrido os artigos e, embora não falasse português, tinha conseguido perceber do que se tratava, por isso queria conversar comigo.

Assim, fui muito generosamente acolhida nesse meio que estava fazendo a teoria literária mais influente no mundo, naquele momento. Fiquei muito amiga de Philippe Sollers e Julia Kristeva, que depois perdi de vista, de Tzvetan Todorov, que vejo ainda de vez em quando, e eram essas as pessoas que eu freqüentava. De 1972 a 1975, a Fundação de Amparo à Pesquisa do Estado de São Paulo me deu uma bolsa para preparar a livre-docência sobre os críticos escritores. Esses dois anos e meio em Paris foram muito intensos, porque convivi com escritores e críticos e comecei a publicar em revistas francesas.

Vou ler, agora, um trecho do posfácio que escrevi recentemente, para a reedição do meu livro Texto, critica, escritura:

O que vejo claramente agora é que, ao escrever este livro, eu era uma espécie de Monsieur Jourdain. Como essa personagem de Molière, que falava em prosa sem o saber, em 1975 eu era pós-estruturalista sem o saber, já que esse rótulo, duvidoso como todos os "pós", ainda não existia. A verdade é que tive a oportunidade excepcional de não apenas acompanhar as teorias dos pensadores franceses da década de 1970, mas de conviver com eles em Paris, e de participar dos debates com artigos meus nas principais revistas em que eles mesmos publicavam: Tel Quel, Poétique e La Quinzaine littéraire. Assim, parte deste livro sobre os "críticos-escritores" foi publicada no no 27 de Poétique (1976), com o título "L'intertextualité critique". Esse número se tornou referência internacional sobre a questão da intertextualidade, tendo sido traduzido em várias línguas.

Eu não tinha, então, consciência de estar participando de uma elaboração teórica tão importante. Tudo ia acontecendo, e eu achava que era natural. Só a 
posteriorié que a gente vê o que foi importante. Como que por acaso, mas nada é por acaso, em 1980 passei um ano na Universidade de Yale, como pesquisadora e conferencista. Fui por circunstâncias alheias a questões teóricas, mas na verdade eu estava indo para os Estados Unidos no momento em que a teoria francesa estava se deslocando para lá. Naquela cidade tão calma, naquela pasmaceira de New Haven, tive a oportunidade de pesquisar em sua magnífica biblioteca e de conversar muito com Paul de Man e outros críticos da "escola de Yale". De Man me convidou para fazer uma conferência sobre Barthes, por ocasião do falecimento deste. Era também a época em que Jacques Derrida ensinava em Yale. Derrida foi uma pessoa de imensa importância na minha vida, fiquei muito amiga dele nos últimos dez anos, e infelizmente o mundo o perdeu em 2004.

Depois disso, em 1997, passei uma boa temporada na Universidade de Montréal, dando um curso de pós-graduação em Literatura Comparada. À medida que eu ia completando minha carreira de professora de Literatura Francesa, fui me tornado naturalmente comparatista ou "generalista". Logo que me aposentei, fui convidada para ensinar Literatura Portuguesa e Brasileira na Sorbonne, de 1988 a 1991, onde dei aulas sobre Fernando Pessoa, Mário de Andrade e Carlos Drummond de Andrade. Em 1991, dei um minicurso sobre Clarice Lispector na École Pratique de Hautes Études.

Refletindo sobre meu percurso, vejo o seguinte. Minha posição na crítica literária brasileira é ligeiramente marginal, primeiramente porque fiz minha carreira em Literatura Francesa, numa época em que a influência francesa já estava em declínio, no Brasil e no mundo. O nacionalismo, tão fortemente afirmado pelo nosso Modernismo, e mais tarde defendido pela esquerda brasileira, fez com que os críticos de maior prestígio no Brasil do século XX fossem aqueles que se dedicaram prioritariamente à literatura brasileira - o que eu acho muito justo. Só que sempre fui muito cobrada, em nome de uma suposta obrigação de me dedicar a uma crítica militante de literatura brasileira. Fui às vezes chamada de "colonizada" e de "elitista", porque era afrancesada.

Ora, o fato é que sempre considerei o nacionalismo literário um estreitamento de visão. E o alargamento do meu interesse por obras de outras literaturas, além da francesa e da brasileira, à qual tenho me dedicado muito mais do que parece, vem da convicção de que a grande literatura é universal, não depende das condições nacionais em que ela se manifesta.' patrimônio da humanidade.

Vou fazer agora um excurso sobre dois livros que diferem um pouco de minha produção como crítica literária, fundamentalmente de literatura francesa ou de teoria da crítica. Meu livro Fernando Pessoa, aquém do eu, além do outro (1982) nasceu de um artigo que publiquei na revista Tel Quel, em 1974, num tempo em que quando alguém conhecia o poeta na França, acrescentava: "Fernando Pessoa, ce curieux poète portugais". Hoje, tenho a alegria de ver que, no mundo inteiro, quando se fala em Pessoa, ninguém precisa acrescentar mais nada, 
porque ele está internacionalmente conhecido. Esse meu livro, que teve uma reedição ampliada em 2002, com uma parte sobre o Livro do desassossego, que era inédito quando publiquei a primeira edição. É, talvez, o meu melhor livro, porque nasceu de uma paixão pela poesia. Eu estava na França - conto isso no prefácio - há dois anos, falando francês diariamente, e de repente Pessoa me veio, e isto foi uma volta à língua portuguesa. Não foi por um brasileiro, mas por um português. Esse excurso pela literatura portuguesa, afinal, não era tão inesperado porque, quando terminei o meu curso de Letras, como ainda não havia pós-graduação, fiz cursos de especialização em Literatura Francesa e em Literatura Portuguesa. Eu já tinha uma grande paixão por essa maravilhosa poesia portuguesa, e não só por Fernando Pessoa, mas também por Camilo Pessanha, Cesário Verde e Mário de Sá-Carneiro, sobre os quais escrevi mais tarde.

Em 1992 houve outro excurso, quando descobri a história do primeiro viajante francês no Brasil, Paulmier de Gonneville, que teria estado em Santa Catarina três anos depois de Cabral e levado para a França um índio, filho do cacique carijó, a quem ele chamava de Essomericq (talvez fosse Iça-Mirim). Fiquei fascinada por essa história, a única história realmente bonita das relações entre descobridor e índio do século XVI. Contei essa história em Vinte luas Viagem de Paulmier de Gonneville ao Brasil - 1503-1505 (1992), com o qual recebi o Prêmio Jabuti. É um livro que tem sido reeditado no Brasil e, traduzido na França, esgotou-se.

Atualmente está havendo, por lá, uma polêmica a respeito da viagem de Gonneville, na qual eu não gostaria de entrar. Escrevi o livro porque gostei da história, e escrevi-a com base em todos os documentos que existiam. Para mim, é uma "viagem" que eu já fiz. Mas agora tenho sido obrigada a voltar a ela, porque há "negacionistas" da viagem de Gonneville, a meu ver com argumentos que não se sustentam. Enfim, não é o momento aqui de falar sobre isso. Esses debates, se os documentos são totalmente autênticos ou não, se é História ou apenas história, interessam aos historiadores. Eu, como literária, acho que tudo é história. Aquela bela história continua sendo uma bela história, tendo ocorrido ou não. E tendo perdurado na memória coletiva durante quinhentos anos, já faz parte da História. Isto pode parecer uma posição escandalosa para os historiadores, mas eu a assumo como literária que sou.

Estou me encaminhando para o presente, isto é, para a minha atividade atual. Nunca trabalhei tanto quanto depois da minha aposentadoria. É trabalho sem parar. Em 1978, eu tinha criado, na área de pós-graduação de Língua e Literatura Francesa na USP, um projeto intitulado "Projeto Léry-assu", sobre as relações da literatura brasileira com a literatura francesa. Isso porque, orientando teses de literatura francesa, um dia, presa no trânsito de São Paulo - o que, como vocês vêem, tem algumas vantagens, porque se pode ficar pensando -, eu tinha entrevistado alunos que queriam fazer teses sobre Racine, sobre Balzac, e pensei: esses alunos vão passar anos de suas vidas trabalhando sobre autores que têm 
uma bibliografia enorme, vastíssima, e o trabalho deles, por melhor que for, vai ser uma gotinha no oceano. E há tanta coisa para ser feita sobre aquilo que passou da literatura francesa para a literatura brasileira, não simplesmente como influência, isto é, dependência, mas como incorporação, porque os grandes escritores não sofrem influências, eles incorporam e transformam em outra coisa, transformam na sua própria obra.

Criei então esse projeto, que se chamava "Léry-assu" porque, quando Jean de Léry chegou ao Rio de Janeiro no século XVI, os índios perguntaram o nome dele e "Leri", em tupi, queria dizer ostra. Então os índios o apelidaram de Leriassu, isto é, "Ostra Grande". Eu sempre digo que ele teve mais sorte que o bispo Sardinha. Vai ver que os índios não gostavam de ostra, porque Léry, vindo também do mar e se chamando "ostra", não foi devorado. E como meu projeto tinha uma ótica "antropofágica", pretendia buscar o que a literatura brasileira devorou da literatura francesa e como a transformou, tinha esse nome. Os índios não devoraram Léry, mas devoraram seu nome. Isso tem uma seqüência porque, atualmente, coordeno o Núcleo de Pesquisa Brasil-França no Instituto de Estudos Avançados da Universidade de São Paulo, onde há um grupo de colegas, vários oriundos daquele projeto, que trabalham sobre questões França-Brasil. A Universidade de São Paulo, fundada por mestres sobretudo franceses, continua tendo ainda uma forte ligação com a França.

Atualmente também dirijo a Coleção Roland Barthes, da Editora Martins Fontes, que está reeditando as antigas traduções, com revisões rigorosas, algumas inteiramente refeitas, e editando os inéditos de Roland Barthes, porque só a partir 2000 é que nós conhecemos toda a sua obra. Agora está para sair um volume de inéditos intitulado Política, que é único no mundo, porque nem a França tem um volume de Barthes que reúna os escritos dele sobre política. Já saíram os inéditos Teoria e Crítica, ou seja, artigos que estavam esparsos em jornais, em revistas, em publicações italianas, inglesas, e que nunca tinham sido incorporados nos livros dele. $\mathrm{E}$ os últimos cursos que ele deu, principalmente o que está para sair, que é $A$ preparação do romance. Ele faleceu pelas seqüelas de um atropelamento diante do Collège de France, aonde estava indo para preparar as últimas sessões desse seminário, um seminário maravilhoso, que tive o trabalho e o prazer imenso de traduzir eu mesma. É um seminário que durou dois anos, e que vai desde o haicai japonês até Proust, isto é, da forma mais breve à mais extensa. Foi um curso de grande amor pela literatura, que Barthes considerava em processo de extinção.

Atualmente, também, sou pesquisadora do CNPq e trabalho num projeto que se intitula "A literatura em mutação: produção, crítica e ensino". Além disso, estou traduzindo Le livre à venir, de Maurice Blanchot, um livro fundamental que, por causa de problemas de contrato com Portugal, ainda não tínhamos podido traduzir no Brasil. Foi um livro muito importante em minha formação. Resenhei esse livro no Suplemento Literário em 1960, e só agora o estou traduzindo. 
Para terminar, e para sair do "odioso eu", algumas palavras sobre o ensino da literatura e a crítica literária. Muitas coisas mudaram desde que me tornei crítica literária. A mais importante e a mais grave é que a literatura, tal como era concebida na alta modernidade, perdeu muito de seu prestígio. A criação literária não é mais concebida como uma das mais nobres atividades humanas, uma "vocação" à qual o escritor dedicava todas suas forças e podia até sacrificar sua vida. A literatura, atualmente, é apenas uma das atividades de comunicação, uma atividade como qualquer outra, que dá prestígio e, às vezes, muito dinheiro.

No ensino, o que é mais grave, a Literatura é uma disciplina ameaçada. No curso secundário, as aulas de Literatura vêm sendo substituídas por cursos de Comunicação e Expressão. A palavra "literatura" quase nem aparece nas Diretrizes do Ministério da Educação. Aliás, nossa área agora se chama "Linguagens, códigos e suas tecnologias". Essa questão do ensino da literatura veio à tona há dois ou três anos, depois ninguém mais falou disso, mas eu aconselho, sobretudo os acadêmi-cos que têm o poder de intervir nesses assuntos, a verem um pouco as Diretrizes Curriculares para os cursos de Letras do Ministério de Educação, não só do se-cundário mas do universitário, onde a palavra 'literatura' é quase ausente. Quando ela aparece, é para falar de Guimarães Rosa como alguém que é interessante porque mostra uma região de Minas Gerais, costumes e falas locais. Ou então, pior ainda, para dizer que os professores não devem ser elitistas e seus cursos devem corresponder ao repertório e aos gostos dos alunos. No caso de um aluno que disse "eu acho Drummond de Andrade um chato", a professora afirma: "ele tem o direito de achar isso". Ora, que um aluno diga que acha Drummond um chato, isso deveria ser um magnífico estímulo para o professor. Qual é o nosso papel? É mostrar que ele está enganado, e porque. É ensinar a ler.

A Literatura é uma disciplina ameaçada. Digo isso com absoluta certeza. Quando escrevi Altas literaturas, muitos me chamaram de apocalíptica. Não acho que a literatura como tal esteja acabando. A produção não, a produção não tem de ser vigiada, nem palpitada por ninguém. A literatura segue o caminho que ela terá de seguir. A literatura está em mutação, como sempre esteve. E se não sabemos muito bem para onde ela está indo, é porque ainda não temos os parâmetros para aferir isso. Os escritores criarão esses parâmetros, e cabe aos críticos reconhecê-los.

Mas como formar novos leitores e novos escritores sem o conhecimento da literatura do passado? Nos cursos de Comunicação e Expressão do secundário, os textos literários têm o mesmo status que qualquer outro tipo de texto. A orientação do Ministério da Educação não£é causa do declínio do ensino de Literatura, é sintoma, porque são as equipes que fazem os pareceres e elaboram os currículos que tomam determinados rumos. Aliás, o desprestígio progressivo do ensino da alta literatura, ou da literatura difícil, representada pelos textos canônicos ocidentais, é um fato histórico universal. 
Esse desprestígio tem numerosas razões:

1. Vivemos numa época de informação coletiva e rápida, e a leitura literária é uma atividade solitária, lenta e que, para ser bem feita, precisa ser apreendida.

2. Respostas simples às grandes questões filosóficas e existenciais passaram a ser buscadas, por aqueles que ainda lêem, em manuais de auto-ajuda, mais reconfortantes do que os textos literários.

3. O relativismo cultural dominante põe em xeque as antigas escalas de valores, sem as substituir por novas. $\mathrm{Na}$ Universidade os estudos culturais de inspiração norte-americana valorizam em seus temas o "politicamente correto", isto é, o conteúdo ideológico das obras, e desconfiam do cânone ocidental, "eurocêntrico".

Tenho tratado polemicamente dessas questões, e não vou voltar a elas. Quanto ao conteúdo dos estudos culturais, do ponto de vista político, estou perfeitamente de acordo com eles, com as causas que são defendidas, como não poderia deixar de estar. Mas que a literatura seja usada para defesas de causas políticas ou de supostas "minorias", é algo que eu, como uma velha professora de Literatura, não posso aceitar.

Portanto, como instituição a literatura está em declínio. O que está em questão não é a salvação da literatura como prática de escrita ou de leitura. A literatura, nas grandes formas de ficção e poesia, continua sendo largamente praticada e consumida, como o comprovam as grandes tiragens editoriais, o afluxo de um largo público aos eventos literários, cursos livres, salões do livro, bienais, prêmios etc., se bem que, nesses eventos, a alta literatura é o que menos se busca.

A literatura como prática não precisa de nenhuma defesa especial. O que está em questão, curiosamente, é a salvação da literatura como disciplina escolar e universitária. A ameaça sofrida pela disciplina Literatura tem caráter universal, como o comprovam os numerosos debates a esse respeito realizados, primeiramente, em países como os Estados Unidos, onde a polêmica surgiu e, em 1995, a maior associação literária americana, a Modern Language Association - e isso está registrado - considerou a literatura "finished for good" no ensino.

$\mathrm{Na}$ França houve polêmicas curriculares de alcance nacional, que fizeram cair um ministro em 2000. No Brasil, o "desaparecimento" da Literatura no ensino, tão evidente como naqueles países, tem causado pouca comoção. A maior associação brasileira de professores de Literatura, a Associação Brasileira de Literatura Comparada (Abralic), em seu último congresso, realizado em Porto Alegre, em agosto de 2004, não tinha uma única mesa dedicada ao ensino da Literatura.

Esse é um assunto vastíssimo, mas estou encerrando. Há um buraco enorme entre um secundário anticanônico e os programas canônicos dos vestibulares, porque os mesmos alunos que são ensinados - se é que a isto se pode chamar de ensino - a tratar fragmentos de textos literários como um texto de jornal ou 
uma carta, quando chegam ao vestibular, têm de enfrentar o programa canônico. O que acontece? Acontece a simplificação dos cursinhos, porque os alunos não lêem tudo o que deveriam; lêem os resumos, sabem o que dizer de cada um daqueles autores, e são muito poucos os que lêem. Daí a queixa geral dos professores, não só de literatura, pelo fato de os alunos não saberem escrever e não gostarem de ler.

Há também um paradoxo - tudo isso são problemas nacionais, e é por isso que estou aproveitando este lugar para falar disso - na criação de bibliotecas sem que a escola se preocupe em formar leitores. Ensinar literatura é ensinar a ler textos complexos. Sem leitura não há cultura. A pretensa democratização do ensino - a "Universidade para todos" - como nivelação baseada na "realidade" dos alunos redunda em injustiça social. $\mathrm{O}$ argumento de que se devem oferecer ao aluno apenas textos ao seu alcance, ou oriundos do seu ambiente social, é um paternalismo e um menosprezo da capacidade dos jovens.

Ainda sobre o ensino da literatura, o que é subversivo hoje não é a militância política em sala de aula. O que é subversivo é ensinar poesia, pois, como diz Adorno, "qualquer que seja a sua temática, a poesia desvenda o fundamento qualitativo da sociedade. A grandeza da obra de arte é deixar falar aquilo que a ideologia dissimula". Colocações muito semelhantes a essas de Adorno, às quais eu poderia acrescentar as de muitos outros grandes teóricos, estão num discurso sobre "A poesia lírica e a sociedade", de 1958, escrito por Antonio Candido, e numa conferência que ele fez em 1988, intitulada "O direito à literatura". Nessa conferência, ele fala da literatura como um "bem incompreensível a que todos têm direito, e que deveria ser acrescentado aos direitos do homem”. Coincidentemente, na sua última aula no Collège de France, Roland Barthes também disse que o direito à literatura deveria constar nos direitos humanos.

O ensino de literatura de qualquer nacionalidade não é elitista, mas democratizante. O livro ainda é o objeto cultural mais barato e acessível. O texto do Dom Quixote ou de Dom Casmurro é o mesmo, num volume encadernado em papel bíblia ou num exemplar de banca de jornal. Se os leitores de literatura constituem uma elite, esta é aberta a todos os alfabetizados, cabendo aos professores apenas mostrar o objeto sob a sua melhor luz.

Ora, o texto literário tem uma especificidade e um valor que devem ser preservados. Atualmente, há muita informação cultural circulando, o que não redunda em cultura, porque essas informações são superficiais, indiferenciadas, veiculadas sem nenhum critério de seleção e recebidas de modo aleatório. É como um antídoto a essa indiferenciação generalizada da informação que a literatura deve ser ensinada e estudada. A grande obra literária é meio de conhecimento, de crítica do real e exercício da liberdade imaginativa, sem a qual a história é vivida como fatalidade. $\mathrm{O}$ acesso às obras dotadas desses valores e ao instrumental que permite a sua melhor fruição é um direito ao qual corresponde um dever do professor e do crítico. 
Se me permitirem uma citação pessoal, com valor meramente documental, eu dizia, acerca da minha profissão, em 1982: “Que se possa assegurar a sobrevivência material, com palavras ditas e escritas, e palavras sobre a palavra inútil da literatura, é algo que me encanta como um milagre". Foi um depoimento que dei, porque achava milagroso poder viver como professora de Literatura. Já naquela época eu costumava dizer: "Professor de Literatura vai ser uma profissão esquecida no futuro, como a de meirinho ou de anspeçada". Esse milagre continua a me espantar, e tenho até certo receio de chamar atenção para ele, temendo que a sociedade ainda mantenha professores de literatura e críticos literários por mera distração, e de repente se dê conta de que nós não temos nenhuma utilidade. Entretanto, minha certeza não da utilidade imediata, mas do valor permanente da literatura jamais se abalou. A certeza não me vem apenas do prazer e do saber que a literatura me tem dado pela vida afora, mas também, e principalmente, da resposta de sucessivos grupos de alunos e leitores a esse valor que eu tenho podido modestamente repassar-lhes.

Muito obrigada.

REsumo - CONSIDERAÇões expostas na Academia Brasileira de Letras por Leyla PerroneMoisés sobre seu percurso como crítica literária. A ensaísta comenta suas primeiras leituras, sua experiência de juventude como pintora e participante do Ateliê Abstração de Samson Flexor, sua iniciação na crítica literária no Suplemento Literário de O Estado de S. Paulo, sua carreira universitária como especialista de literatura francesa e, depois, como comparatista, suas temporadas de estudo e de ensino no exterior. E exprime, finalmente, sua preocupação com o ensio da literatura nos cursos secundário e universitário.

PALAVRAs-CHAVE: Literatura, Arte, Crítica, Jornalismo, Ensino.

ABSTRACT - CONSIDERATIONS delivered at the Brazilian Academy of Literature by Leyla Perrone-Moisés on her career as a literary critic. The essayist comments upon her first readings, her youthful experiences as a painter and member of Samson Flexor's Abstraction Atelier, her initiation in literary criticism in the "Literary Supplement" of the O Estado de São Paulo newspaper, her academic career as a French literature scholar and, later, as a comparatist, her sojourns abroad to study and teach. Finally, she shares her concerns over the teaching of literature in secondary schools and universities.

KEr-WORDS: Literature, Art, Criticism, Journalism, Teaching.

Leyla Perrone-Moisés é professora titular aposentada da Faculdade de Filosofia, Letras e Ciências Humanas da Universidade de São Paulo, e coordenadora do Núcleo de Pesquisa Brasil-França no Instituto de Estudos Avançados da USP. @ - leylapm@usp.br

Recebido em 28.8.05 e aceito em 30.8.05. 